\title{
PEMBELAJARAN KIMIA MELALUI METODE EKSPERIMEN BERBASIS LINGKUNGAN ALAM SEKITAR DITINJAU DALAM PERSPEKTIF ISLAM
}

\author{
Buchori Muslim, Zulfiani, Dedi Irwandi \\ Universitas Islam Negeri (UIN) Syarif Hidayatullah Jakarta \\ Email: bucek.uin.jakarta07@gmail.com
}

\begin{abstract}
This paper aims at describing teaching and learning activities in chemistry lesson through environmental-based (contextual-based) experiments that are viewed from the perspective of Islam. Islam teaches its followers to study their environment in order to find solution for many problems. One of the problems posed by chemistry teachers with regards to conducting chemistry experiments is the lack of laboratory equipments. In fact, if environment has been studied well, Islam has provided anything we need including the need to conduct chemistry experiment. Verses in Quran, especially al-Baqarah: 185, anNisa: 28, al-Hajj: 78, and Hud: 61 implied that our environment provides more than enough for us to do experiments. The problem of not doing the experiments was that because teachers are not studying their environment well enough. This paper describes some ideas in which environment helps chemistry teachers to be able to conduct chemistry experiments without losing the chemistry concept.
\end{abstract}

Keywords: Chemistry learning, experiments based on the natural environment surrounding

\begin{abstract}
Abstrak: Tulisan ini bertujuan untuk mendapatkan deskripsi pembelajaran kimia melalui metode eksperimen berbasis lingkungan alam sekitar yang ditinjau dalam perspektif Islam. Banyak para guru tidak melaksanakan praktikum kimia dengan alasan ketidaktersediaannya peralatan laboratorium. Islam mengajarkan kepada pengikutnya untuk tidak mempersulit proses pembelajaran misalnya pada kegiatan praktikum kimia seperti yang dinyatakan dalam surat al-Baqarah : 185, an-Nisa: 28, dan al-Hajj: 78. Islam memberikan solusi seperti yang tertuang dalam surat Hud: 61, dengan memanfaatkan lingkungan alam sekitar (peralatan sehari-hari) untuk praktikum kimia, sehingga tidak ada lagi alasan bagi para guru untuk tidak melaksanakan praktikum kimia.
\end{abstract}

Kata Kunci: pembelajaran Kimia, eksperimen berbasis lingkungan alam sekitar

\section{Pendahuluan}

Pendidikan ilmu kimia merupakan bagian dari pendidikan Ilmu Pengetahuan Alam (IPA) yang memiliki peranan yang sangat penting dalam kehidupan sehari-hari manusia, seperti yang dikatakan oleh John $\mathrm{H}$. Postlethwait, dkk yaitu: "By understanding chemistry, you will understand life". Yang artinya dengan mempelajari ilmu kimia seseorang akan memahami makna hidup yang sebenarnya. Pernyataan ini jelas menunjukkan bahwa seseorang yang mengerti ilmu kimia tentu akan berbeda dengan orang yang tidak mengerti ilmu

\footnotetext{
${ }^{1}$ John H. Postlethwait dkk, Biology Bringing Science to Life, (United States of America: McGraw-Hill, 1991), p. 22.
}

kimia dalam menjalani kehidupan. Hal ini sesuai dengan firman Allah SWT yang berbunyi:

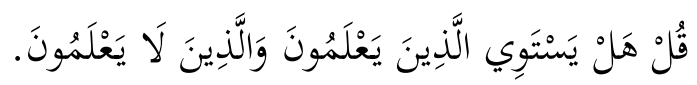

Artinya: Katakanlah: "Apakah sama orang-orang yang mengetahui dengan orang-orang yang tidak mengetahui?”. (QS. Az-Zumar ayat: 9).

Indonesia saat ini memberlakukan dua kurikulum yaitu Kurikulum Tingkat Satuan Pendidikan (KTSP) dan Kurikulum 13 (K13). KTSP merupakan kurikulum yang berorientasi pada pencapaian kompetensi yang menekankan keterlibatan siswa secara aktif dan berusaha menemukan konsep sendiri dalam proses pembelajaran di semua mata pelajaran termasuk kimia dan tentu ini disesuaikan dengan sarana 
dan prasarana satuan pendidikan yang ada. ${ }^{2}$ Sedangkan K13 lebih menekankan pada pengembangan karakter siswa dalam proses pembelajaran. Terdapat 18 karakter yang dikembangkan dalam proses pembelajaran K13, di antaranya: religius, jujur, toleransi, disiplin, kerja keras, kreatif, mandiri, demokratis, rasa ingin tahu, semangat kebangsaan, cinta tanah air, menghargai prestasi, bersahabat/komunikatif, cinta damai, gemar membaca, peduli lingkungan, peduli sosial dan tanggung jawab.

Guru sebagai fasilitator, katalisator dan pendorong siswa diharapkan memberikan kesempatan pada siswa menemukan atau menerapkan sendiri gagasan-gagasan mereka untuk belajar, sekaligus dapat menanamkan karakter yang menjadi tuntutan kurikulum indonesia. Namun kenyataan menunjukkan bahwa metode pembelajaran konvensional masih mendominasi dalam proses pembelajaran yang menyebabkan rendahnya aktivitas, minat serta hasil belajar siswa terhadap pelajaran IPA khususnya kimia. Padahal, jika melihat pengertian IPA itu sendiri menurut Fisher dalam Wira Sanjaya IPA adalah: "suatu kumpulan pengetahuan yang diperoleh dengan menggunakan metode-metode yang berdasarkan observasi".

Untuk melakukan perbaikan terhadap rendahnya aktivitas, minat serta hasil belajar siswa disarankan pembelajaran berlangsung sebagai berikut ${ }^{4}$ : (1) dari konkret menuju abstrak; (2) dari yang mudah menuju yang sulit; (3) dari yang sederhana menuju yang rumit. Dari saran tersebut nampak jelas bahwa metode yang tepat untuk mencapai hal tersebut adalah melalui metode eksperimen karena metode ini dapat

\footnotetext{
${ }^{2}$ Wina Sanjaya, Kurikulum dan Pembelajaran: Teori dan Praktik Pengembangan Kurikulum Tingkat Satuan Pendidikan (KTSP), (Jakarta: Kencana, 2010), h. 127.

${ }^{3}$ Wina Sanjaya, Kurikulum dan Pembelajaran, h. 4.

${ }^{4}$ Noehi Nasution, Pendidikan IPA di SD, (Jakarta: Universitas Terbuka, 2005), h. 15.
}

mengubah kejadian yang sangat kompleks menjadi lebih sederhana. ${ }^{5}$

Kegiatan eksperimen dapat dilakukan di laboratorium atau di luar laboratorium seperti di sekolah, di rumah, dan sebagainya. ${ }^{6}$ Siswa akan lebih mudah memahami konsep yang rumit dan abstrak jika disertai contoh-contoh yang konkret, contoh-contoh yang wajar sesuai dengan kondisi yang dihadapi, dengan mempraktikkannya sendiri. Siswa juga dapat mempelajari kimia melalui pengamatan langsung terhadap gejalagejala maupun proses kimia, dapat melatih keterampilan berpikir ilmiah, dapat menanamkan dan mengembangkan sikap ilmiah, dapat menemukan dan memecahkan berbagai masalah baru melalui metode ilmiah tersebut.

Kenyataan menunjukkan bahwa masih terdapat beberapa sekolah di Indonesia yang tidak memiliki laboratorium kimia. Padahal menurut hadits Nabi Saw, yang diriwayatkan oleh Imam Bukhari dikatakan bahwa:

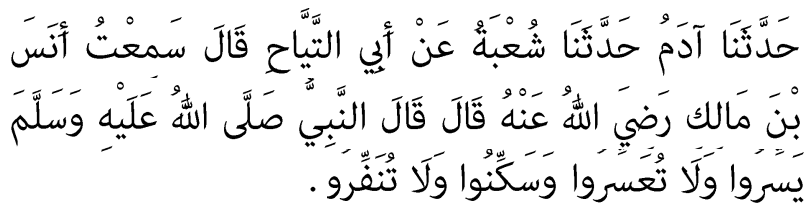

Yang artinya: "Mudahkanlah setiap urusan \& janganlah kalian mempersulitnya, buatlah mereka tenang \& jangan membuat mereka lari". (HR. Bukhari No.5660).

Untuk mengatasi hal ini guru dapat menunjukkan kreativitasnya dengan memanfaatkan bahan sehari-hari yang dapat ditemukan di lingkungan alam sekitar sebagai sumber belajar agar kendala yang dihadapi dalam melaksanakan eksperimen dapat $\mathrm{di}$ atasi. Eksperimen yang dilakukan tidak selalu harus dilaksanakan di dalam laboratorium tetapi dapat dilakukan pada alam sekitar. ${ }^{7}$ Metode eksperimen berbasis lingkungan alam sekitar digunakan sebagai pengganti bahan kimia yang tidak tersedia di laboratorium dan harganya

\footnotetext{
${ }^{5}$ Noehi Nasution, Pendidikan IPA di SD, h. 26.

${ }^{6}$ Noehi Nasution, Pendidikan IPA di SD, h. 225.

${ }^{7}$ Noehi Nasution, Pendidikan IPA di SD, h. 517.
} 
relatif mahal. Alat dan bahan pengganti tersebut sangat mudah diperoleh dan harganya jauh lebih murah, namun dapat dijadikan sebagai bahan eksperimen kimia.

Tujuan penulisan artikel ini untuk mendapatkan pembelajaran kimia melalui metode eksperimen berbasis lingkungan alam sekitar yang ditinjau dalam perspektif Islam. Peran Islam dalam proses pembelajaran memberikan kemudahan dalam mendapatkan peralatan yang dibutuhkan untuk kegiatan eksperimen yaitu dengan memanfaatkan lingkungan alam sekitar, seperti yang tertuang dalam Al-Qur'an surat Hud ayat 61, sehingga tidak ada alasan bagi guru kimia untuk tidak melaksanakan eksperimen atau demonstrasi dalam pembelajaran, terutama untuk mencapai kompetensi yang diharapkan.

\section{Tinjauan Tentang Belajar dan Hasil Belajar}

Menurut Al-Qur'an definisi belajar dinyatakan dalam surat al-'Alaq ayat 1-5 yang merupakan wahyu pertama yang diturunkan Allah kepada Nabi Muhammad SAW yakni perintah untuk membaca (iqra'). Mengapa iqra' merupakan perintah pertama yang ditujukan kepada nabi, padahal beliau seorang yang $U m m i$ (yang tidak pandai membaca dan menulis)? Iqra' terambil dari akar kata yang berarti "menghimpun" sehingga tidak selalu harus diartikan "membaca teks tertulis dengan aksara tertentu". Dari menghimpun lahir aneka ragam makna, seperti: menyampaikan, menelaah, mendalami, meneliti, mengetahui ciri sesuatu, dan membaca, baik tertulis maupun tidak. Hasil belajar merupakan hal yang sangat penting yang akan dijadikan sebagai tolok ukur sejauh mana keberhasilan seorang siswa dalam belajar. Dari hasil belajar, guru dapat menilai apakah sistem pembelajaran yang diberikan berhasil atau tidak,

\footnotetext{
${ }^{8}$ Akyas Azhari, Psikilogi Umum dan Perkembangan, (Bandung: Seri Buku Daras, 2004), h. 122
}

untuk selanjutnya bisa diterapkan atau tidak dalam proses pembelajaran.

\section{Metode Eksperimen}

Metode eksperimen ialah suatu metode mengajar di mana guru bersama siswa mencoba mengerjakan sesuatu serta mengamati proses dari hasil eksperimen itu. Kegiatan eksperimen merupakan kegiatan aplikasi dari teori-teori yang telah dipelajari untuk memecahkan berbagai masalah IPA melalui percobaan-percobaan di laboratorium.

Menggunakan metode eksperimen melibatkan kegiatan inquiry dan discovery di mana kegiatan inqury seperti yang dikatakan Douglas Llewellyn adalah: "inquiry is an approach to learning that involves a process of exploring the natural or material world, and that leads to asking question, making discoveries, and testing those discoveries in the search for new understanding". ${ }^{10}$ Yaitu sebuah pendekatan belajar yang melibatkan proses menjelajahi dunia alam atau materi, dan yang mengarah ke mengajukan pertanyaan, membuat penemuan, dan pengujian penemuan-penemuan dalam mencari pemahaman baru. Sedangkan definisi lain mengatakan bahwa: "Inquiry is a process where students are involved in their learning, formulate questions, investigate widely and then build new understanding, meanings and knowledge"." Yaitu inkuiri merupakan sebuah proses di mana siswa terlibat dalam pembelajaran mereka, merumuskan pertanyaan, menyelidiki secara luas dan kemudian membangun pemahaman baru, makna dan pengetahuan. Dengan melakukan penyelidikan, siswa dapat meningkatkan kecerdasan, seperti yang dikatakan

\footnotetext{
9 Moh. Amien, Mengajarkan Ilmu Pengetahuan Alam (IPA) Dengan Menggunakan Metode "Discovery" dan "Inquiry", (Jakarta: Depdikbud Dirjen P2LPTK, 1987), h. 95.

${ }^{10}$ Douglas Llewellyn, Inquiry Within: Implementing InquiryBased Science Standards In Grades 3-8, (United States of America: Corwin Press, 2007), p. 11.

${ }^{11}$ Alberta, Focus on Inquiry: A Teachers Guide to Implementing Inquiry-based Learning, (Canada: Alberta Learning, 2004), p. 1
} 
oleh Douglas Llewellyn yaitu: "in inquiry, students can enhance their naturalistic intelligence through observing and recognizing patterns from the environment and surroundings". ${ }^{12}$ Yang artinya dalam kegiatan inkuiri siswa dapat meningkatkan kecerdasan alami mereka melalui mengamati dan mengenali pola dari lingkungan dan sekitarnya.

Selain melibatkan kegiatan inqury, eksperimen juga melibatkan kegiatan discovery yang merupakan komponen penting dari pendekatan konstruktivisme yang mempunyai sejarah panjang dalam inovasi pendidikan. ${ }^{13}$ Dalam kegiatan discovery terdapat langkahlangkah yang harus diperhatikan guru saat melakukan kegiatan discovery seperti yang dijelaskan oleh Richard Boyatzis dalam Douglas Llewellyn yaitu ${ }^{14}$ :

"The first step involves forming an image of the ideal self, where you reflect on your professional aspirations and the kind of teacher you want to become.... The second step of discovery is assessing your real selt-who you are right now, how you teach, and your deep-seated beliefs about how children learn.... In the third step, consider a professional development plan that leads you from the present state to the desired state.... The fourth step involves gaining new strategies and improving your performance through continuous practice and reflection.... The final step entails finding a support system".

Menurut Ibn Rusdi dalam Deborah L. Black penalaran dengan metode eksperimen berguna untuk memperkuat syariat itu sendiri, dalam hal ini penguasaan terhadap konsep-konsep kimia. ${ }^{15}$

\footnotetext{
${ }^{12}$ Douglas Llewellyn, Inquiry Within, h. 33

${ }^{13}$ Robert E. Slavin, Psikologi Pendidikan: Teori dan Praktik, (Jakarta: PT. Indeks, 2009), Edisi ke-8, h. 10.

${ }^{14}$ Douglas Llewellyn, Inquiry Within, p. 2-3

${ }^{15}$ Deborah L. Black, "Al-Fârâbî", in Seyyed Hossein Nasr dan Olive Leaman, ed. Ensiklopedi Tematis Filsafat Islam (Buku Kedua), Terj. Tim Penerjemah Mizan, (Bandung: Mizan, 2003), h. 40
}

\section{Eksperimen Berbasis Lingkungan Alam Sekitar}

Dalam proses pembelajaran menggunakan metode eksperimen dibutuhkan alat dan bahan yang dapat menunjang pelaksanaan kegiatan tersebut, namun kenyataan menunjukkan bahwa alat dan bahan yang dibutuhkan tidak tersedia di laboratorium. Untuk mengatasi hal tersebut, Islam mengajarkan untuk memberikan kemudahan dalam proses pembelajaran, tetapi tidak menghendaki kesukaran. Banyak dalil dari al-Qur'an dan as-sunnah yang menunjukkan hal ini, di antaranya firman Allah:

$$
\text { يُرِيدُ اللَّهُ بِكُمُ الْيْسْرَ وَلَا يُرِيدُ بِكُمُ الْعُسْرَ. }
$$

Artinya: "Allah menghendaki kemudahan bagimu, dan tidak menghendaki kesukaran bagimu." (QS. al-Baqarah/2: 185).

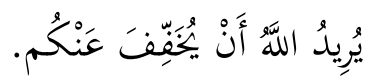

Artinya: "Allah hendak memberikan keringanan kepadamu.” (QS. an-Nisa: 28).

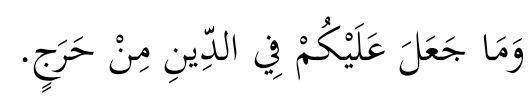

Artinya: "Dan Dia sekali-kali tidak menjadikan untuk kamu dalam agama (termasuk didalamnya proses pembelajaan) suatu kesempitan atau kesukaran.” (QS. al-Hajj/22: 78)

Adapun dari as-sunnah, diantaranya: Dari Abu Hurairah R.A bahwa Nabi Saw bersabda.

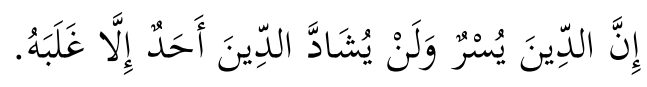

Artinya: "Sesungguhnya agama (termasuk di dalamnya proses pembelajaan) itu mudah, dan tidaklah seseorang mempersulit agama (proses pembelajaran) kecuali dia akan dikalahkan (semakin berat dan sulit)." (HR. al-Bukhari no. 38). 
Dari Abu Umamah al-Bahili R.A secara marfu':

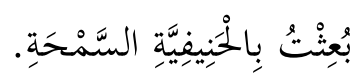

Artinya: "Aku diutus dengan membawa agama (proses pembelajaran) yang bertauhid lagi mudah.” (HR. Ahmad: 5/266 dan dinyatakan shahih oleh al-Albani dalam ash-Shahihah no. 2924).

Dari Abu Qatadah dari seorang Badui yang mendengar dari Rasulullah Saw bahwa beliau bersabda:

$$
\text { إِنَّ خَيْرَ دِينِكُمْ أَيْسَرُهُ إِنَّ خَيْرَ دِينِكُمْ أَيْمَرُهُ. }
$$

Artinya: "Sebaik-baik perkara agama (proses pembelajaran) kalian adalah yang paling mudah urusannya, sungguh sebaik-baik perkara kalian adalah yang paling mudah urusannya." (HR. Ahmad: 3/852 dan dinyatakan hasan oleh alAlbani dalam Shahih al-Adab al-Mufrad no. 124)

Proses pembelajaran melalui metode eksperimen berbasis lingkungan alam sekitar merupakan pembelajaran yang mengintegrasikan unsur lingkungan dalam proses pembelajaran yang bertujuan membantu siswa mendapatkan makna dari pembelajaran, sehingga membentuk siswa menuju perilaku yang sadar lingkungan, tanggap terhadap perubahan yang terjadi dan dapat memecahkan masalah dalam lingkungan. Lingkungan atau alam sekitar mencakup segala hal yang ada di sekitar manusia yang mempengaruhinya. Lingkungan belajar ini terbagi menjadi tiga jenis: (1) Lingkungan Sosial; (2) Lingkungan Buatan; (3) Lingkungan Alam Sekitar. ${ }^{16}$

Jenis lingkungan yang akan dimanfaatkan sebagai sumber belajar dalam penelitian ini yaitu jenis lingkungan alam sekitar, sesuai dengan perintah Allah dalam al-Qur'an surat Hud ayat 61:

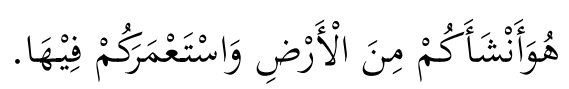

\footnotetext{
${ }^{16}$ Uus Ruswandi, Badrudin, Media Pembelajaran, (Bandung: CV. Insan Mandiri, 2008), h. 131
}

Artinya: "Dia (Allah) telah menciptakan kamu dari bumi (tanah) dan memerintahkan kalian untuk memakmurkannya (memanfaatkannya)”.

Metode eksperimen berbasis lingkungan alam sekitar memanfaatkan lingkungan sebagai media pembelajaran yang akan menjadikan proses belajar lebih bermakna karena para siswa dihadapkan pada bahan-bahan yang nyata yang berada disekitar mereka sehingga mereka termotivasi dalam belajar. Dari lingkungan seorang guru bisa memanfaatkan alat dan bahan yang sudah ada bisa dengan cara memodifikasinya. Alat dan bahan sehari-hari dapat diperoleh di rumah, di sekolah, atau di lingkungan tempat tinggal siswa. ${ }^{17}$

Kelebihan yang diperoleh dari kegiatan mempelajari lingkungan dalam proses belajar mengajar antara lain:

1) Kegiatan belajar lebih menarik dan tidak membosankan, sehingga motivasi belajar siswa semakin tinggi.

2) Hakikat belajar akan lebih bermakna, sebab siswa dihadapkan dengan situasi dan keadaan yang sebenarnya dan bersifat alami.

3) Bahan-bahan yang dapat dipelajari lebih kaya serta lebih faktual, sehingga kebenarannya lebih akurat.

4) Kegiatan belajar siswa lebih komprehensif dan lebih aktif, sebab dapat dilakukan dengan berbagai cara.

5) Sumber belajar menjadi lebih kaya, sebab lingkungan yang dapat dipelajari bisa beraneka ragam.

6) Siswa dapat memahami dan menghayati aspek-aspek yang ada di lingkungannya. ${ }^{18}$

Berdasarkan pernyataan di atas dapat disimpulkan bahwa eksperimen berbasis lingkungan alam sekitar yaitu suatu proses kegiatan eksperimen (praktikum) di mana alat dan bahan yang digunakan berasal dari lingkungan sekitar siswa dan murah harganya, dan eksperimen ini diharapkan dapat

\footnotetext{
${ }^{17}$ Noehi Nasution, Pendidikan IPA di SD, h. 21.

${ }^{18}$ Uus Ruswandi, Badrudin, Media Pembelajaran, h.129-130.
} 
meningkatkan pemahaman konsep siswa terhadap ilmu kimia.

Dalam penerapan eksperimen berbasis lingkungan alam sekitar tidak serta merta digunakan alat dan bahan yang berasal dari lingkungan, terlebih lagi dalam hal pendidikan di mana harus memberikan bukti dalam setiap langkah dan tindakan yang dikerjakan. Untuk mengatasi hal tersebut perlu memperhatikan beberapa pertimbangan dalam asas pendidikan, yaitu :

1) Biaya yang murah baik saat pembelian maupun dalam pengoperasian dan pemeliharaan.

2) Kesesuaian dengan metode pengajaran yang dipakai.

3) Kesesuaian dengan karakteristik mahasiswa.

4) Pertimbangan praktis, kemudahan, keamanan, kesesuaian dengan fasilitas yang ada, keawetan, kemudahan pemeliharaan.

5) Ketersediaan alat dan bahan berikut di pasaran. $^{19}$

\section{Implementasi Pembelajaran kimia dengan Metode Eksperimen Berbasis Lingkungan Alam Sekitar Ditinjau dalam Perspektif Islam}

Islam merupakan agama yang fleksibel dan tidak menyulitkan orang-orang yang mengikuti ajarannya yang dikenal dengan istilah rahmatanlil âlamín. Peran Islam di sini justru memberikan kemudahan pengikutnya untuk melakukan berbagai aktivitas dalam menjalani kehidupan, dalam hal ini proses pembelajaran Kimia dengan menggunakan metode eksperimen. Metode eksperimen Kimia ini pertama kali dilakukan oleh ilmuwan muslim yang bernama Jabir ibn Hayyan dalam Dalmeri, di mana beliau melakukan eksperimen yang pertama mengenai perubahan biji yang kusam menjadi

\footnotetext{
${ }^{19}$ Engkoswara, Dasar-dasar Metodologi Pengajaran, (Jakarta: Bina Aksara, 1988), hal. 75
}

berkilau. Logam-logam biasa ini kemudian berubah menjadi logam mulia. ${ }^{20}$

Ilmuwan muslim lainnya yang ikut memberikan kontribusi terhadap eksperimen kimia yaitu: al-Razi atau Rhazes dan 'Izz al-Din al-Jaldaki. Beberapa senyawa yang berhasil ditemukan Jabir ibn Hayyan yaitu: Asam Sulfat $\left(\mathrm{H}_{2} \mathrm{SO}_{4}\right)$, Asam Nitrat $\left(\mathrm{HNO}_{3}\right)$, Aqua Regia (pelarut kuat), Besi (Fe), dan Alkohol. Penemuan lainnya terbukti setelah 200 tahun kewafatannya, ketika penggalian tanah dilakukan untuk pembuatan jalan, laboratoriumnya yang telah punah ditemukan, di dalamnya didapati peralatan kimianya yang hingga kini masih bagus dan sebatang emas yang cukup berat. Jabir bin Hayyan membuat instrumen pemotong, peleburan dan pengkristalan. Ia menyempurnakan proses dasar sublimasi, penguapan, pencairan, kristalisasi, pembuatan kapur, penyulingan, pencelupan, pemurnian, fixation, amalgamasi, dan oksidasi-reduksi. Ada 200 judul buku karya umat muslim yang diadopsi oleh orang Eropa, di antaranya: Kitab al-Ushûl al-Kimyâi, Kitab al-Syam al-Kâmil, Kitab al-'Asah, dan Kitab al-Jâmi. Masa kejayaannya berakhir hingga abad ke-11, yang kemudian dilanjutkan perkembangannya di dunia barat.

Adapun implementasi pembelajaran kimia menggunakan penerapan metode eksperimen berbasis lingkungan alam sekitar ditinjau dalam perspektif Islam yang dijelaskan dalam artikel ini berupa langkah-langkah pembelajaran disertai lembar kerja siswa (LKS) yang bertujuan untuk memandu siswa menemukan konsep melalui kegiatan pengamatan dan eksperimen.

LKS merupakan materi ajar yang sudah dikemas sedemikian rupa sehingga siswa diharapkan dapat mempelajari materi ajar tersebut secara mandiri. ${ }^{21}$ Definisi lain

\footnotetext{
${ }^{20}$ Dalmeri dan Setiadi, Asep, "Perkembangan Ilmu Kimia di Dunia Muslim (Menggali Sains Islam Tepat Guna)”, Jurnal Ilmiah Faktor Exacta 1(2), 2008.

${ }^{21}$ Denny setiawan, dkk. Pengembangan Bahan Ajar, (Jakarta: Universitas Terbuka, 2009), edisi ketiga, h. 225.
} 
mengatakan LKS adalah lembaran-lembaran berisi tugas yang harus dikerjakan oleh peserta didik. Lembar kegiatan biasanya berupa petunjuk dan langkah-langkah untuk menyelesaikan suatu tugas. Lembar kegiatan untuk mata pelajaran IPA harus disesuaikan dengan pendekatanpendekatan pembelajaran IPA. ${ }^{22}$

LKS terbagi menjadi dua yaitu LKS eksperimen dan LKS non-eksperimen, namun LKS yang dikembangkan dalam penelitian ini merupakan LKS eksperimen berbasis lingkungan alam sekitar yang berisi prosedur praktikum IPA khususnya kimia di laboratorium dengan bahan dan alat yang mudah diperoleh di lingkungan sehari-hari siswa.

Adapun sintak atau langkah-langkah yang dapat dilakukan guru bersama dengan siswa jika akan mencoba menciptakan eksperimen berbasis lingkungan alam sekitar ditinjau dalam perspektif Islam adalah sebagai berikut: ${ }^{23}$

\section{1) Pelajari secara mendalam materi ajar tersebut,} lalu coba cari hubungan setiap konsep yang ada dengan fenomena yang ada dalam kehidupan sehari-hari.

Mempelajari materi ajar Kimia secara mendalam memerlukan kemampuan berpikir tingkat tinggi yang melibatkan level kognitif tingkat analisis. Dalam al-Qur'an sebanyak 49 kali Allah menjelaskan bahwa sungguh beruntung bagi orang-orang yang selalu mau berpikir. Allah mengistimewakan bagi mereka yang menggunakan akal pikirannya, seperti yang tertulis dalam Al-Qur'an surat al-Mujadilah ayat 11 yang menjelaskan bahwa "Allah akan mengangkat derajat orang-orang yang beriman dan berilmu pengetahuan”. Misalnya pada konsep laju reaksi, Buchori Muslim, dkk melakukan eksperimen berbasis bahan sehari-hari dalam penelitiannya tentang faktor-faktor yang

\footnotetext{
22 Poppy Kamalia Devi, dkk. Pengembangan Perangkat Pembelajaran (Bandung: PPPPTK IPA, 2009), h. 32

23 Das Salirawati, dkk., "Pelatihan Pengembangan Praktikum IPA Berbasis Lingkungan”. Artikel Jurnal Inotek. (Yogyakarta: Lembaga Pengabdian Kepada Masyarakat, Universitas Negeri Yogyakarta, 2010).
}

mempengaruhi laju reaksi, yaitu: untuk menyelidiki pengaruh suhu terhadap laju reaksi ia melarutkan gula dalam air dengan suhu yang berbeda-beda (air biasa, dingin dan panas), untuk menyelidiki pengaruh konsentrasi terhadap laju reaksi ia mereaksikan kulit telur dengan larutan cuka (konsentrasi larutan cuka divariasikan), untuk menyelidiki pengaruh luas permukaan terhadap laju reaksi ia juga mereaksikan kulit telur dengan larutan cuka (hanya saja ukuran kulit telur yang divariasikan: serbuk, butiran, kepingan dan telur utuh), untuk menyelidiki pengaruh katalis terhadap laju reaksi ia mengoleskan abu pada gula batu dan membakarnya (dalam hal ini abu berfungsi sebagai katalis). ${ }^{24}$

2) Setelah kita dapat menemukan suatu fenomena, cobalah berpikir bagaimana mengangkat fenomena tersebut menjadi suatu rancangan percobaan sederhana.

Menemukan fenomena dan mengangkat fenomena tersebut menjadi suatu rancangan percobaan melibatkan kemampuan berpikir pada level sintesis. Lagi-lagi Allah menekankan kepada hamba-hamba-Nya untuk selalu berpikir. Adapun alat dan bahan sehari-hari yang digunakan untuk menggantikan alat dan bahan sintetik dapat dilihat pada tabel 2.1

Tabel 1 Daftar Alat dan Bahan Sehari-hari. ${ }^{25}$

\begin{tabular}{llcl}
\hline No & Nama Alat dan Bahan & No & Nama Alat dan Bahan \\
\hline A & Suhu & C & Luas Permukaan \\
1 & Air $100 \mathrm{~mL}$ (air biasa, & 1 & Kulit telur \\
& dingin dan panas) & & \\
2 & Gelas aqua & 2 & Gelas aqua \\
3 & Gula serbuk & 3 & Larutan cuka \\
$\mathbf{4}$ & Alat pengukur waktu (jam) & 4 & Gunting \\
5 & Sendok teh & 5 & Alat pengukur waktu (jam \\
\hline
\end{tabular}

${ }^{24}$ Buchori Muslim., dkk., "Efforts to Improve Learning Outcomes Through Chemistry Experiment Method Based on Daily Material in Class XI Science at MAN Cipondoh Tangerang", Proceeding of The International Conference on Education in Muslim Society (ICEMS)-UIN Syarif Hidayatullah Jakarta, 2014, h. 250.

${ }^{25}$ Buchori Muslim., dkk., "Efforts to Improve Learning Outcomes Through Chemistry Experiment Method Based on Daily Material in Class XI Science at MAN Cipondoh Tangerang”, h. 252. 


\begin{tabular}{llcl}
\hline B & Konsentrasi & D & Katalis (uji nyala api) \\
$\mathbf{1}$ & Kulit telur & 1 & Gula batu \\
2 & Larutan cuka & 2 & Kertas \\
3 & Gelas aqua & 3 & Korek api \\
$\mathbf{4}$ & Alat pengukur waktu (jam) & 4 & Tatakan dari bahan \\
& & & logam/piring kecil \\
\hline
\end{tabular}

Berdasarkan tabel 1 dapat dilihat bahwa alat dan bahan sehari-hari yang dibutuhkan untuk praktikum faktor-faktor yang mempengaruhi laju reaksi yaitu: Untuk praktikum pertama tentang pengaruh suhu terhadap laju reaksi, alat dan bahan sehari-hari yang digunakan yaitu: ${ }^{26}$ Air $100 \mathrm{~mL}$ (air biasa, dingin, dan panas), gelas aqua, gula serbuk, alat pengukur waktu (jam) dan sendok teh. Sedangkan alat dan bahan sintetik yang seharusnya tersedia di laboratorium sekolah yaitu: ${ }^{27}$ kaki tiga dan kasa, pembakar spirtus, termometer, enlenmeyer, tabung reaksi, $\mathrm{HCl}$, Natrium Tiosulfat $\left(\mathrm{Na}_{2} \mathrm{~S}_{2} \mathrm{O}_{3}\right)$ dan alat pengukur waktu (stop watch). Praktikum kedua tentang pengaruh konsentrasi terhadap laju reaksi, alat dan bahan sehari-hari yang digunakan yaitu: ${ }^{28}$ kulit telur, larutan cuka, gelas aqua, gunting dan alat pengukur waktu (jam). Sedangkan alat dan bahan sintetik yang seharusnya tersedia di laboratorium sekolah yaitu: ${ }^{29} \mathrm{CaCO}_{3}$, enlenmeyer, gelas beker, $\mathrm{HCl}$, silinder pengukur, gelas ukur dan alat pengukur waktu (stop watch). Praktikum ketiga tentang pengaruh luas permukaan terhadap laju reaksi, alat dan bahan sehari-hari yang digunakan yaitu: ${ }^{30}$ kulit telur dengan berat yang sama dalam bentuk serbuk, butiran dan kepingan, gelas aqua, larutan cuka, gunting dan alat pengukur waktu (jam). Sedangkan alat dan bahan sintetik yang seharusnya tersedia di laboratorium sekolah

\footnotetext{
${ }^{26}$ Crys Fajar Partana dan Antuni Wiyarsi, Mari Belajar Kimia Untuk SMA-MA Kelas XI IPA, (Jakarta: Pusat Perbukuan, Departemen Pendidikan Nasional, 2009), h. 92-93

${ }^{27}$ Johari dan Rachmawati, Kimia 2 SMA dan MA untuk Kelas $X I$, (Jakarta: Esis, 2009), h. 112-113.

${ }_{28}$ Muchtaridi dan Sandri Justiana, Kimia SMA Kelas X, (Bogor: Quadra, 2007), h. 125.

${ }^{29}$ Johari dan Rachmawati, Kimia 2 SMA dan MA untuk Kelas $X I$, h. 110.

${ }^{30}$ Muchtaridi dan Sandri Justiana, Kimia SMA Kelas $X$, h. 125 .
}

yaitu: ${ }^{31} \mathrm{CaCO}_{3}$, enlenmeyer, $\mathrm{HCl}$, timbangan digital dan alat pengukur waktu (stop watch). Praktikum keempat tentang pengaruh katalis terhadap laju reaksi, alat dan bahan sehari-hari yang digunakan yaitu ${ }^{32}$ : Gula batu, Kertas, Korek api, dan Tatakan dari bahan logam/piring kecil. Sedangkan alat dan bahan sintetik yang seharusnya tersedia di laboratorium sekolah yaitu: ${ }^{33}$ Alat Pengukur Waktu (stop watch), Hidrogen Peroksida $\left(\mathrm{H}_{2} \mathrm{O}_{2}\right), \mathrm{MnO}_{2}$ (katalis), dan Tabung Reaksi.

\section{3) Buatlah langkah-langkah pengujiannya.}

Sebelum melakukan suatu perbuatan, dalam hal ini eksperimen kimia, Islam mengajarkan untuk membuat langkah-langkah pengujian konsep-konsep kimia yang akan dieksperimenkan, sehingga akan diketahui pengujian konsep mana yang akan didahulukan. Seperti yang tertuang dalam QS. al-Insyirah ayat 7 yang berbunyi:

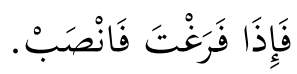

Artinya: "Maka apabila kamu telah selesai (dari sesuatu urusan), kerjakanlah dengan sungguhsungguh (urusan) yang lain”.(QS. al-Insyirah/94: 7).

Adapun langkah kerja dari masing-masing eksperimen berbasis lingkungan alam sekitar tentang faktor-faktor yang mempengaruhi laju reaksi dapat diuraikan sebagai berikut: ${ }^{34}$ ara kerja 1:

1) Siapkan 3 buah gelas aqua sebagai berikut:

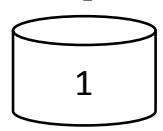

Air biasa

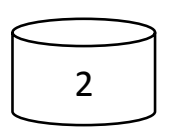

Air panas

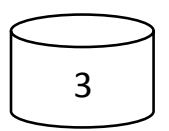

Air dingin
${ }^{31}$ Johari dan Rachmawati, Kimia 2 SMA dan MA untuk Kelas $X I$, h. 111-112.

32 Das Salirawati, Fitria Meilina K, dan Jamil Suprihatiningrum, Belajar Kimia Secara Menarik untuk SMA/MA kelas XI, (Jakarta: PT. Grasindo, 2007), h. 127.

${ }^{33}$ Johari dan Rachmawati, Kimia 2 SMA dan MA untuk Kelas XI, h. 114.

34 Buchori Muslim. "Upaya Meningkatkan Hasil Belajar Kimia Melalui Metode Eksperimen Berbasis Bahan Sehari-hari Pada Siswa Kelas XI IPA MAN Cipondoh Tangerang”, Skripsi, (UIN Jakarta: tidak diterbitkan. 2012). 
2) Masukkan 1 sendok teh gula halus ke dalam masing-masing gelas aqua yang telah diberi tanda. Lalu aduk secara konstan.

3) Siapkan pancatat waktu (Stopwatch atau jam tangan).

4) Catat waktu yang diperlukan untuk melarutkan gula tersebut pada masingmasing gelas aqua.

5) Masukkan data hasil pencatatan waktu yang diperlukan ke dalam tabel hasil pengamatan.

Cara kerja 2:

1) Siapkan 3 buah gelas aqua, beri tanda 1,2, dan 3.

2) Tuangkan larutan cuka ke dalam masingmasing gelas aqua dengan cara: gelas ke-1 berisi $1 / 2$ gelas larutan cuka, gelas ke-2 berisi $1 / 4$ gelas larutan cuka dan encerkan hingga $1 / 2$ gelas, gelas ke-3 berisi $1 / 4$ gelas larutan cuka dan encerkan hingga tanda garis yang ada pada gelas aqua.

3) Masukkan kulit telur serbuk dengan terlebih dahulu memotongnya menjadi segi empat dengan sisi $\pm 2 \mathrm{~cm}$ ke dalam masing-masing gelas aqua yang telah diberi tanda.

4) Siapkan pancatat waktu (Stopwatch atau jam tangan).

5) Catat waktu yang diperlukan, mulai dari memasukkan kulit telur ke dalam masingmasing larutan cuka hingga semua kulit telur habis.

6) Masukkan data hasil pencatatan waktu yang diperlukan ke dalam tabel hasil pengamatan.

Cara kerja 3:

1) Ambil gula batu, lalu buat potonganpotongan kecil dalam bentuk balok (ukuran kira-kira $1 \mathrm{x} 1,5 \mathrm{~cm}$ ), sebanyak 2 potongan.

2) Satu potong gula batu olesi bagian pojokpojoknya (bagian sudut) dengan abu dari bakaran kertas, kemudian letakkan di atas piring kecil. Satu potong lagi tidak perlu diolesi, dan letakkan juga di atas piring kecil yang berbeda.

3) Secara bersamaan, bakar kedua gula batu tersebut pada salah satu pojoknya dengan menggunakan nyala dari korek api.
4) Bandingkan kecepatan terbakarnya kedua gula batu tersebut.

Cara kerja 4:

1) Siapkan 3 buah gelas aqua, beri tanda 1, 2, dan 3.

2) Masukkan kulit telur ke dalam masingmasing gelas aqua yang telah diberi tanda: gelas ke-1 kulit telur berbentuk serbuk, gelas ke-2 kulit telur berbentuk butiran dan gelas ke-3 kulit telur berukuran kepingan.

3) Siapkan pancatat waktu (Stopwatch atau jam tangan).

4) Masukkan $1 / 2$ gelas aqua larutan cuka ke dalam gelas aqua ke-1.

5) Catat waktu yang diperlukan, mulai dari memasukkan larutan cuka sampai dengan habisnya serbuk kulit telur.

6) Lakukan hal yang sama pada gelas ke-2 dan gelas ke-3.

7) Masukkan data hasil pencatatan waktu yang diperlukan ke dalam tabel hasil pengamatan.

4) Ujicobalah sesuai dengan rancangan yang kita buat.

Setelah tersedia alat dan bahan sehari-hari serta prosedur percobaannya, maka yang harus dilakukan adalah melakukan ujicoba atau validasi prosedur eksperimen untuk mendapatkan prosedur eksperimen berbasis lingkungan alam sekitar yang tepat, sehingga eksperimen yang sudah dirancang sesuai dengan yang diharapkan. Hal ini sesuai sabda Rasulullah SAW yang berbunyi:

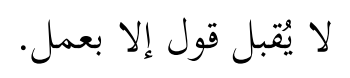

Artinya: "Tidak diterima ucapan kecuali dengan perbuatan (eksperimen)”. (Imam Sufyan alTsauriy).

5) Tulis rancangan kita dengan format urutan sederhana yang terdiri dari: judul, tujuan percobaan, dasar teori, bahan dan alat, cara kerja, tabel dasar (untuk menuliskan data yang harus dikumpulkan), pertanyaan, kesimpulan, dan daftar pustaka 
Sistematika penulisan format seperti ini dilakukan sebagai bentuk dokumentasi suatu produk LKS yang empiris agar dapat dimanfaatkan untuk para pendidik yang akan melakukan kegiatan eksperimen serupa. Diriwayatkan dari Jabir berkata, Rasulullah Saw. bersabda:

$$
\begin{aligned}
& \text { عن جابر قال : قال رسول الله صلى الله عليه وسلم: }
\end{aligned}
$$

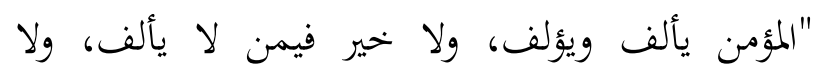

$$
\begin{aligned}
& \text { يؤلف، وخير الناس أنفعهم للناس". }
\end{aligned}
$$

Artinya: "Orang beriman itu bersikap ramah dan tidak ada kebaikan bagi seorang yang tidak bersikap ramah. Dan sebaik-baik manusia adalah orang yang paling bermanfaat bagi orang lain". (HR. Thabrani dan Daruquthni)

Adapun uraian masing-masing komponen yang dimaksud adalah sebagai berikut: ${ }^{35}$

1) Judul: memuat garis besar dari konsep yang akan dipraktikumkan.

2) Tujuan Percobaan: memuat tujuan yang berkaitan dengan permasalahan yang diungkapkan dalam dasar teori.

3) Dasar Teori: berisi uraian singkat yang mengetengahkan bahan pelajaran (berupa konsep-konsep IPA) yang dicakup dalam kegiatan/praktikum.

4) Alat dan Bahan: memuat alat dan bahan yang diperlukan.

5) Cara Kerja: intruksi untuk melakukan kegiatan. Untuk mempermudah siswa melakukan praktikum, langkah kerja ini dibuat secara sistematis. Bila perlu menggunakan nomor urut dan menambah tampilkan sketsa gambar.

6) Tabel Dasar: berupa tabel-tabel data untuk mencatat data hasil pengamatan yang diperoleh dari hasil praktikum.

7) pertanyaan: berupa pertanyaan yang jawabannya dapat membantu siswa untuk

\footnotetext{
35 Poppy Kamalia Devi, dkk. Pengembangan Perangkat Pembelajaran, h. 32-33.
}

mendapatkan konsep yang dikembangkan atau untuk mendapatkan kesimpulan.

8) Kesimpulan: merupakan simpulan akhir dari hasil percobaan.

9) Daftar Pustaka: sumber yang menjadi rujukan dalam kegiatan percobaan.

Contoh di atas merupakan salah satu eksperimen berbasis lingkungan alam sekitar ditinjau dalam perspektif Islam, di mana peralatan yang digunakan mudah didapatkan dalam kehidupan sehari-hari siswa. Peran Islam disini yaitu memberikan kemudahan bagi setiap pengikutnya dengan menggantikan peralatan yang tidak tersedia dalam laboratorium dengan peralatan yang tersedia dari lingkungan alam sekitar siswa. Bahkan Allah dan Rasul-Nya menganjurkan untuk mempermudah suatu urusan dan bukan mempersulit. Beberapa konsep lain yang dapat disampaikan melalui metode eksperimen tersebut, yaitu: larutan elektrolit dan non elektrolit, reaksi eksoterm dan endoterm, pembuatan larutan, faktor-faktor yang mempengaruhi laju reaksi, asam-basa, penentuan $\mathrm{pH}$ larutan, larutan penyangga, kelarutan dan hasil kali kelarutan, hidrolisis garam, efek tyndal (dalam larutan sejati, koloid, dan suspensi), sifatsifat koloid (koagulasi), penjernihan air, kenaikan titik didih dan penurunan titik beku larutan, elektrokimia (sel volta dan elektrolisis), dan korosi.

Setelah melakukan kegiatan eksperimen, Islam menganjurkan untuk melakukan diskusi terkait konsep yang dieksperimenkan. Seperti yang tertuang dalam firman Allah yang berbunyi:

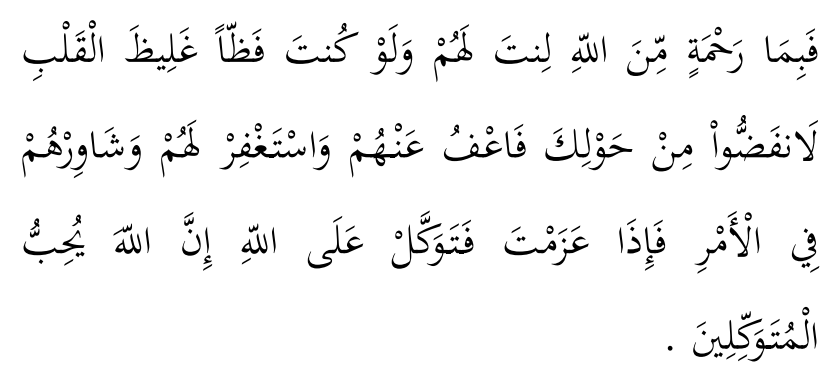

Artinya: "Maka disebabkan rahmat dari Allah-lah kamu berlaku lemah lembut terhadap mereka. Sekiranya kamu bersikap keras lagi berhati kasar, 
tentulah mereka menjauhkan diri dari sekelilingmu. Karena itu ma'afkanlah mereka, mohonkanlah ampun bagi mereka, dan bermusyawarahlah dengan mereka dalam urusan itu. Kemudian apabila kamu telah membulatkan tekad, maka bertawakkallah kepada Allah. Sesungguhnya Allah menyukai orang-orang yang bertawakkal kepada-Nya. (QS. Ali Imran: 159).

Pendapat lain yang hampir sama terkait pelaksanaan diskusi atau yang dikenal dengan istilah musyawarah yaitu kegiatan diskusi dilakukan siswa secara berkelompok, seperti yang dikatakan oleh Douglas Llewellyn yaitu: "the children worked in the small groups, deciding how they would go about answering their investigative questions. ${ }^{, 36}$ Yang artinya anak-anak bekerja dalam kelompok kecil yang terdiri dari 56 orang siswa, mereka memutuskan bagaimana menjawab pertanyaan-pertanyaan yang diajukan guru melalui kegiatan eksperimen berbasis lingkungan alam sekitar. Douglas Llewellyn juga mengatakan: "In this classroom, student sit in straight rows of desks facing the front of the class and have few opportunities to interact or work in cooperative learning groups". ${ }^{37}$ Maksudnya dengan pelaksanaan eksperimen yang dilanjutkan dengan kegiatan diskusi hasil eksperimen ini membuat siswa memiliki beberapa peluang untuk berinteraksi dalam sebuah kelompok, baik dalam kelompok sendiri maupun dengan kelompok lain dan ini berarti aktivitas siswa dalam proses pembelajaran akan meningkat. Dengan adanya kegiatan eksperimen yang merupakan pengalaman langsung dalam proses belajar ini menunjukkan bagaimana satu prinsipprinsip ilmiah atau kebenaran berlaku untuk hidup.

Pada hakikatnya, dalam kegiatan eksperimen berbasis lingkungan alam sekitar ini para pendidik harus memperhatikan tujuan-tujuan

\footnotetext{
${ }^{36}$ Douglas Llewellyn, Inquiry Within, h. 42.

${ }^{37}$ Douglas Llewellyn, Inquiry Within, h. 54.
}

instruksional yang antara lain diharapkan agar siswa dapat: ${ }^{38}$

1) Terampil dalam mengamati, mencatat data pengukuran dan manipulasi alat serta pembuatan alat-alat yang sederhana.

2) Jujur dalam menyusun laporan hasil percobaan.

3) Teliti dan cermat dalam bekerja serta mengenal batas-batas kemampuannya dalam pengukuran-pengukuran.

4) Nalar secara kritik.

5) Memperdalam pengetahuan inkuiri dan dapat memecahkan masalah.

6) Mengembangkan sikap imiah.

7) Memahami, memperdalam dan menghayati IPA

8) Mendisain dan melaksanakan percobaan dengan peralatan sederhana.

Banyaknya bantuan dan bimbingan yang diberikan guru kepada siswanya tidak membatasi kebebasan siswa untuk melakukan penemuan sendiri. Akan tetapi hal tersebut ditentukan oleh tujuan pembelajaran dan waktu yang tersedia. ${ }^{39}$

\section{Penutup}

Berdasarkan penjelasan di atas dapat disimpulkan bahwa sintak pembelajaran Kimia melalui metode eksperimen berbasis lingkungan alam sekitar yang ditinjau dalam perspektif Islam, yaitu: Pertama, dengan mempelajari secara mendalam materi yang akan diajarkan, lalu mencari hubungan setiap konsep yang ada dengan fenomena yang ada dalam kehidupan sehari-hari. Kedua, setelah menemukan suatu fenomena, cobalah berpikir bagaimana mengangkat fenomena tersebut menjadi suatu rancangan percobaan sederhana. Ketiga, membuat langkah-langkah pengujian/pembuktiannya. Keempat, melakukan ujicoba sesuai dengan rancangan yang dibuat. Kelima, menuliskan rancangan dengan format urutan

${ }^{38}$ Moh. Amien, Mengajarkan Ilmu Pengetahuan Alam (IPA), h. 96.

${ }^{39}$ Noehi Nasution, Pendidikan IPA di SD, h. 3,22. 
sederhana yang terdiri dari: judul, tujuan percobaan, dasar teori, bahan dan alat, cara kerja, tabel dasar, pertanyaan, kesimpulan, dan daftar pustaka. Dari lima langkah tersebut sesuai dengan ajaran Islam, di mana pada langkah pertama dan kedua Islam memerintahkan pengikutnya untuk menggunakan akal, dalam hal ini berpikir. Level berpikir (kognitif) yang digunakan berada pada tingkat analisis dan sintesis. Langkah ketiga merupakan cerminan perintah Islam yang menganjurkan kepada pengikutnya untuk membuat prosedur (langkahlangkah) sebelum melakukan perbuatan. Sedangkan untuk langkah keempat dan kelima merupakan anjuran Islam bahwa "sebaik-baik do'a atau permintaan yaitu dengan perbuatan", dan Islam sangat mengapresiasikan bahwa setiap karya yang dihasilkan dituliskan dalam bentuk sistematika penulisan laporan sehingga dapat dimanfaatkan untuk orang-orang yang membutuhkan. Sesuai dengan sabda Nabi Saw, yang berbunyi:

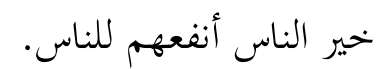

Artinya: "Sebaik-baik manusia adalah orangorang yang bermanfaat untuk orang lain". (HR. Thabrani dan Daruquthni).

Peralatan yang digunakan untuk menggantikan peralatan yang tidak tersedia di laboratorium bergantung pada jenis praktikum yang akan dilakukan. Misalnya untuk eksperimen tentang faktor-faktor yang mempengaruhi laju reaksi, yaitu: pengaruh suhu terhadap laju reaksi, alat dan bahan sehari-hari yang digunakan yaitu: Air $100 \mathrm{~mL}$ (air biasa, dingin dan panas), gelas aqua, gula serbuk, alat pengukur waktu (jam) dan sendok teh. Pengaruh konsentrasi terhadap laju reaksi, alat dan bahan sehari-hari yang digunakan yaitu: kulit telur, larutan cuka, gelas aqua, gunting dan alat pengukur waktu (jam). Pengaruh luas permukaan terhadap laju reaksi, alat dan bahan sehari-hari yang digunakan yaitu: kulit telur dengan berat yang sama dalam bentuk serbuk, butiran dan kepingan, gelas aqua, larutan cuka, gunting dan alat pengukur waktu (jam). Pengaruh katalis terhadap laju reaksi, alat dan bahan sehari-hari yang digunakan yaitu: gula batu, kertas, korek api, dan Tatakan dari bahan logam/piring kecil.

\section{Daftar Pustaka}

Alberta, Focus on Inquiry: A Teachers Guide to Implementing Inquiry-based Learning, Canada: Alberta Learning, 2004.

Amien, Moh., Mengajarkan Ilmu Pengetahuan Alam (IPA) Dengan Menggunakan Metode "Discovery" dan "Inquiry", Jakarta: Depdikbud Dirjen P2LPTK, 1987.

Azhari, Akyas, Psikilogi Umum dan Perkembangan, Bandung: Seri Buku Daras, 2004.

Dalmeri, \& Setiadi, Asep, Perkembangan Ilmu Kimia di Dunia Muslim (Menggali Sains Islam Tepat Guna). Jurnal Ilmiah Faktor Exacta 1(2), 2008.

Devi, Poppy Kamalia, dkk., Pengembangan Perangkat Pembelajaran, Bandung: PPPPTK IPA, 2009.

Engkoswara, Dasat-dasar Metodologi Pengajaran, Jakarta: Bina Aksara,1988.

Fajar Partana, Crys, \& Wiyarsi, Antuni, Mari Belajar Kimia Untuk SMA-MA Kelas XI IPA, Jakarta: Pusat Perbukuan, Departemen Pendidikan Nasional, 2009.

Johari, \& Rachmawati, Kimia 2 SMA dan MA untuk kelas Xl, Jakarta: Esis, 2009.

Llewellyn, Douglas, Inquiry Within: Implementing Inquiry-Based Science Standards in Grades 3-8, United States of America: Corwin Press, 2007.

Muchtaridi, \& Justiana, Sandri, Kimia SMA Kelas X, Bogor: Quadra, 2007.

Muslim, Buchori., dkk., Efforts to Improve Learning Outcomes Through Chemistry Experiment Method Based on Daily Material in Class XI Science at MAN Cipondoh Tangerang, 
Pembelajaran Kimia Melalui Metode Eksperimen ....(Buchori M., Zulfiani, Dedi I.) |201

Proceeding of The International Conference on Education in Muslim Society (ICEMS)-UIN Syarif Hidayatullah Jakarta, 2014.

Muslim, Buchori, "Upaya Meningkatkan Hasil Belajar Kimia Melalui Metode Eksperimen Berbasis Bahan Sehari-hari pada Siswa Kelas XI IPA MAN Cipondoh Tangerang", dalam Skripsi S1 UIN Jakarta: tidak diterbitkan, 2012.

Nasution, Noehi, Pendidikan IPA di SD, Jakarta: Universitas Terbuka, Cet. Ke-1, 2005.

Postlethwait, John H., dkk., Biology! Bringing Science to Life, United States of America: McGraw-Hill, 1991.

Ruswandi, Uus, \& Badrudin, Media Pembelajaran, Bandung: CV. Insan Mandiri, 2008.
Sanjaya, Wina, Kurikulum dan Pembelajaran: Teori dan Praktik Pengembangan Kurikulum Tingkat Satuan Pendidikan (KTSP), Jakarta: Kencana, 2010.

Salirawati, Das., dkk., Pelatihan Pengembangan Praktikum IPA Berbasis Lingkungan. Artikel Jurnal Inotek, Yogyakarta: Lembaga Pengabdian Kepada Masyarakat Universitas Negeri Yogyakarta, 2010.

Salirawati, Das, Fitria Meilina K, \& Jamil Suprihatiningrum, Belajar Kimia Secara Menarik untuk SMA/MA kelas Xl, Jakarta: PT. Grasindo, 2007.

Slavin, Robert E., Psikologi Pendidikan: Teori dan Praktik, Jakarta: PT. Indeks, Edisi ke-8, 2009. 
202 | TARBIYA | Vol. I, No.2, Desember 2014 